\title{
Az uniós jog alkalmazásáért felelős nemzeti bíróságok függetlensége
}

\section{LEHÓCZKI BALÁZS}

Az uniós jog alkalmazásában elsödleges szerepet ellátó nemzeti biróságok függetlenségének biztositását maga az uniós jog követeli meg a tagállamoktól, amelyek ezért a nemzeti igazságszolgáltatási rendszereik terén fennálló kizárólagos hatáskörüket e követelmény tiszteletben tartásával kötelesek gyakorolni. A Bíróságnak két, a közelmúltban lezárt ügyben alkalma nyílt az uniós jogot alkalmazó nemzeti bíróságok függetlensége terjedelme és korlátai egyes szempontjainak a megvizsgálására, aminek keretében új elemekkel bővitette a területen fennálló itélkezési gyakorlatát.

A C-619/18. sz. Bizottság kontra Lengyelország ügyben a Bíróság kimondta, hogy a lengyel legfelsőbb bíróság bíráinak nyugdijkorhatárát a 65. életévre csökkentö lengyel szabályozás ellentétes az uniós joggal, mivel az sérti a bírák elmozdithatatlanságának elvét és a bírói függetlenség elvét.

A C-64/16. sz. Associação Sindical dos Juizes Portugueses ügyben a Bíróság megállapitotta, hogy a portugál számvevőszék birái illetményének a Portugália számára az Unió által elöírt takarékossági intézkedések keretében való csökkentése nem sérti a bírói függetlenség elvét. A Bíróság szerint ugyanis, jóllehet az érintett bírák azon meggyöződése, hogy a javadalmazásuk szintje összhangban áll az általuk ellátott feladatok fontosságával szerves alkotórészét képezi a birák függetlenségének, azonban a jelen esetben olyan, a közszolgálat egészét érintö, időben korlátozott hatályú intézkedésekről volt szó, amelyek céljukat tekintve nem ellentétesek az uniós joggal, és nem tekinthetök a birói hatalom elleni támadásként.

A Bíróság elött jelenleg is számos ügy van folyamatban a bírói függetlenség elvének tiszteletben tartásával kapcsolatban, amelyekben az uniós bíráknak lehetöségük lesz ezen elv tartalmának további pontosítására. Ezen Magyarországot, Lengyelországot és Romániát érintő ügyekben olyan kérdésekröl kell majd dönteni, mint a törvényhozó és a végrehajtó hatalom ráhatása az igazságszolgáltatásra, a bírósági vezetök kinevezésének módja, a birák javadalmazásának a megfelelösége, a bírák által elkövetett jogsértések kivizsgálásának a módja, valamint a bírák az igazságszolgáltatási tevékenységük során elkövetett hibákért való pénzügyi felelössége. 


\section{The Independence of National Courts Applying EU Law}

National courts play a fundamental role in the application of EU law, which therefore requires the Member States to exercise their competence to organise the judiciary by complying with the principle of the independence of judges. The Court of Justice recently delivered judgments in two cases in which it had the occasion to examine certain aspects of the extent and the limits of the independence of national courts applying EU law.

In Case C-619/18 Commission v Poland, the Court ruled that the Polish legislation concerning the lowering of the retirement age for Polish Supreme Court judges is contrary to EU law, since it breaches the principles of the irremovability of judges and judicial independence.

In Case C-64/16 Associação Sindical dos Juizes Portugueses, the Court set out that the salary reductions applied to the judges of the Tribunal de Contas in Portugal as part of austerity measures aiming at reducing the Portuguese State's excessive budget deficit, do not infringe the principle of judicial independence. Although the Court recognised that the receipt by the members of a national court of a level of remuneration commensurate with the importance of the functions they carry out constitutes a factor which is essential to judicial independence, it pointed out that the austerity measures in question indiscriminately applied to the whole public sector, were temporary in nature, pursued a legitimate objective, and, as such, could not be regarded as an attack against the judiciary.

There are still a lot of cases in progress before the Court as to compliance with the principle of independence of judges, which concern Hungary, Poland and Romania. In these cases, the Court has been asked to rule in subjects such as the influence of the executive and the legislative powers on the judiciary, the nomination of presidents of courts, the adequacy of remuneration of judges, investigations into irregularities committed by judges, as well as the financial liability of judges for errors they made in the course of their judicial activity.

\section{Bevezetés}

Az Unió egyes tagállamaiban a jogállamiság helyzetével kapcsolatos politikai vitákkal párhuzamosan egyre több olyan ügy érkezik az Európai Bíróságra (a továbbiakban: a Bíróság), amelyekben a tagállami bíróságok függetlenségének megvizsgálására kérik fel az uniós bírákat.

Jóllehet ugyanis a nemzeti igazságszolgáltatási rendszereik kialakítása továbbra is a tagállamok hatáskörébe tartozik, a nemzeti bíróságok azonban részt vesznek az uniós jog alkalmazásában is, ami miatt az Európai Unióról szóló szerződés 19. cikke (1) bekezdésének második albekezdése kifejezetten megköveteli a tagállamoktól, 
hogy teremtsék meg azokat a jogorvoslati lehetőségeket, amelyek az uniós jog által szabályozott területeken a hatékony jogvédelem biztosításához szükségesek.

A szóban forgó területeken biztosítandó hatékony jogvédelem tartalmával kapcsolatban az Európai Unió Alapjogi Chartájának (a továbbiakban: a Charta) 47. cikke pontosítja, hogy mindenkinek joga van arra, hogy ügyét a törvény által megelőzően létrehozott független és pártatlan bíróság tisztességesen, nyilvánosan és észszerű időn belül tárgyalja.

A jelen tanulmányban két olyan ügyet mutatok be, amelyekben a bírák függetlenségének a kérdését vizsgálták meg, és amelyekben a Bíróság fontos megállapításokat tett e függetlenség terjedelme és korlátai vonatkozásában. Az első ügy a lengyel legfelsőbb bíróság bíráinak a kényszernyugdíjazását érinti, míg a második a portugál számvevőszék bírái illetményének az ország gazdasági helyzetére való tekintettel történő csökkentésével kapcsolatos. A tanulmány zárszavában röviden áttekintem a bírák függetlenségének a tárgyában a Bíróság előtt jelenleg is folyamatban lévő magyar, lengyel és román ügyeket.

\section{A C-619/18. sz. Bizottság kontra Lengyelország ügy előzményei}

2018. április 3-án lépett hatályba a legfelsőbb bíróságról szóló új lengyel törvény, amelynek értelmében e bíróság bíráinak nyugdíjkorhatárát 65 évre csökkentették le. Az új nyugdíjkorhatár e törvény hatálybalépésétől alkalmazandó, e bíróság azon bíráira is, akiket ezen időpontot megelőzően neveztek ki. Lehetőség van a legfelsőbb bíróság bírái által teljesített aktív bírói szolgálat 65 . életéven túli meghosszabbítására, ehhez azonban be kell nyújtani egy olyan nyilatkozatot, amely kifejezésre juttatja a bírák azon szándékát, hogy továbbra is el kívánják látni a feladataikat, továbbá igazolást arról, hogy egészségi állapotuk lehetővé teszi az ítélkezést, a meghosszabbítást pedig a Lengyel Köztársaság elnökének engedélyeznie kell. Ezen engedély megadása során a Lengyel Köztársaság elnökét nem köti semmilyen szempont, a határozata ellen pedig nincs helye semmilyen bírósági felülvizsgálatnak.

Így e törvény szerint a legfelsőbb bíróságon szolgálatot teljesítő azon bírák, akik e törvény hatálybalépése előtt vagy legkésőbb 2018. július 3-án betöltötték a 65 . életévüket, kötelesek voltak 2018. július 4-én nyugdíjba vonulni, kivéve ha legkésőbb 2018. május 3-án benyújtották e nyilatkozatot és ezen igazolást, valamint ha a Lengyel Köztársaság elnöke engedélyezte számukra aktív bírói szolgálatuk meghosszabbítását a legfelsőbb bíróságon.

A Bizottság 2018. október 2-án kötelezettségszegés megállapítása iránti keresetet indított a Bíróság előtt. A Bizottság úgy vélte, hogy egyrészt a nyugdíjkorhatár csökkentésével és ennek a legfelsőbb bíróság 2018. április 3-a előtt kinevezett bíráira történő alkalmazásával, másrészt pedig a Lengyel Köztársaság elnöke számára a legfelsőbb bíróság tagjai aktív bírói szolgálatának meghosszabbítása tekintetében diszkrecionális jogkör biztosításával Lengyelország megsértette az EUSZ 19. cikk (1) bekezdésének második albekezdését, valamint a Charta 47. cikkét. 
A Bizottság a tárgyaláson hangsúlyozta, hogy annak ellenére, hogy a jelen eljárásban kifogásolt, legfelsőbb bíróságról szóló törvény rendelkezéseit a 2018. november 21-i törvény módosította, nem egyértelmü, hogy ez a 2018. november 21-i törvény megszünteti-e az állítólagos uniós jogi jogsértéseket, és továbbra is mindenképpen érdek füződik ahhoz, hogy az ügyben a bírói hatalom függetlenségének az uniós jogrendben betöltött jelentős szerepére tekintettel ítélet szülessen.

\section{A Bíróságnak a C-619/18. sz. Bizottság kontra Lengyelország ügyben hozott ítélete}

2019. június 24-én meghozott ítéletében a Bíróság mindenekelőtt emlékeztetett arra, hogy az uniós jog azon az alapvető előfeltevésen alapul, amely szerint minden tagállam osztozik az összes többi tagállammal az EUSZ 2. cikkben említett értékekben, és elismeri, hogy azok osztják ezen értékeket vele. ${ }^{1}$ Ezen előfeltevés maga után vonja és igazolja a tagállamok és különösen a bíróságaik közötti kölcsönös bizalom fennállását ezen, az Unió alapját képező értékek - köztük a jogállamiság - elismerése, és így az azokat végrehajtó uniós jog tiszteletben tartása tekintetében.

Egyébiránt, jóllehet a tagállamok igazságszolgáltatási szervezete ez utóbbiak hatáskörébe tartozik, e hatáskör gyakorlása során a tagállamoknak tiszteletben kell tartaniuk az uniós jogból eredő kötelezettségeiket. Ebből következően a tagállamoknak meg kell teremteniük azokat a jogorvoslati lehetőségeket, amelyek az uniós jog által szabályozott területeken a Charta értelmében vett hatékony bírói jogvédelem biztosításához szükségesek. Konkrétan az EUSZ 19. cikk (1) bekezdésének második albekezdése alapján minden tagállamnak biztosítania kell, hogy jogorvoslati rendszerében, e területeken az uniós jog értelmében vett „bíróságnak” minősülő fórumok teljesítik az ilyen jogvédelem követelményeit. Annak biztosítása érdekében, hogy az olyan szerv, mint a legfelsőbb bíróság maga ilyen védelmet nyújtson, alapvető fontosságú e szerv függetlenségének védelme. Következésképpen a Bizottság által a keresetében vitatott nemzeti szabályok vizsgálhatók az EUSZ 19. cikk (1) bekezdésének második albekezdése szempontjából.

A Bíróság ezt követően megállapította, hogy a bírák bármely külső beavatkozással vagy nyomással szembeni nélkülözhetetlen szabadsága megkövetel bizonyos olyan megfelelő garanciákat, mint az elmozdíthatatlanság, amelyek az ítélethozatal feladatával megbízott személyek védelmére szolgálnak. Az elmozdíthatatlanság elve megköveteli többek között, hogy a bírák hivatalban maradhassanak mindaddig, amíg nem érik el a kötelező nyugdíjkorhatárt, vagy a megbízatásuk lejártáig, ha az határozott időre szól. Ezen, nem teljesen abszolút jellegű elv alól kizárólag akkor lehet kivételt tenni, ha jogszerủ és kényszerítő indokok igazolják, tiszteletben tartva az arányosság

1 E rendelkezés elöírja többek között, hogy az Unió az emberi méltóság tiszteletben tartása, a szabadság, a demokrácia, az egyenlőség, a jogállamiság, valamint az emberi jogok - ideértve a kisebbségekhez tartozó személyek jogait - tiszteletben tartásának értékein alapul. 
elvét. A jelen ügyben a legfelsőbb bíróság bírái nyugdíjkorhatárát csökkentő intézkedésnek az e bíróságon már hivatalban lévő bírákra való alkalmazása azzal a következménnyel jár, hogy ez utóbbiak igazságszolgáltatási feladatainak ellátása idő előtt megszünik. Az ilyen alkalmazás csak akkor engedhető meg, ha jogszerủ céllal igazolható és e céllal arányos, valamint ha a jogalanyokban nem vetnek fel kétségeket az érintett bíróság külső tényezők általi befolyásolhatatlanságára, valamint az ütköző érdekek vonatkozásában való semlegessége tekintetében.

A Bíróság elutasította Lengyelország azon érvét, hogy a legfelsőbb bíróság bírái nyugdíjkorhatárának 65 évre való csökkentése azon szándékból következett, hogy harmonizálják ezen életkort a lengyelországi munkavállalók összességére alkalmazandó általános nyugdíjkorhatárral, és ezzel e bíróság állományának korösszetételét optimalizálják. A legfelsőbb bíróságról szóló új törvény tervezetének indokolása, egy olyan új mechanizmus bevezetése, amely lehetővé teszi a köztársasági elnöknek, hogy diszkrecionális jogkörében határozzon a bírói feladatok így lerövidített ellátásának meghosszabbításáról, és az, hogy a szóban forgó intézkedés az e bíróság hivatalban lévő tagjainak közel egyharmadát érintette - többek között az első elnököt, akinek az alkotmány által biztosított hatéves megbízatása megrövidült - súlyos aggályokat vethetnek fel ugyanis e reform valódi célkitüzései tekintetében. Ezenkívül ezen intézkedés nem tűnik sem megfelelőnek a Lengyelország által hivatkozott célok eléréséhez, sem pedig arányosnak. Következésképpen a Bíróság megállapította, hogy nem igazolható jogszerű céllal a legfelsőbb bíróság bíráinak nyugdíjkorhatárát csökkentő intézkedésnek az e bíróságon már hivatalban lévő bírákra való alkalmazása, és az sérti a bírák elmozdíthatatlanságának elvét, amely a függetlenségük szerves részét képezi.

A Bíróság hangsúlyozta, hogy a bíróságok függetlenségének és pártatlanságának garanciái megkövetelik, hogy az érintett fórum teljesen autonóm módon gyakorolja feladatkörét, és védett legyen az olyan külső beavatkozással vagy nyomással szemben, amely veszélyeztetheti tagjai határozathozatalának függetlenségét, és határozataikat befolyásolhatja, tiszteletben tartva az objektivitást, valamint azt, hogy a jogvita megoldása során semmilyen más érdek ne érvényesüljön. E tekintetben rámutat arra, hogy azon feltételek és eljárási szabályok, amelyeket a legfelsőbb bíróságról szóló új törvény előír a legfelsőbb bíróság bírája feladatai ellátásának a rendes nyugdíjkorhatáron túli esetleges meghosszabbítása vonatkozásában, nem felelnek meg az ilyen követelményeknek. Az ilyen hosszabbítás ugyanis immár a köztársasági elnök döntésétől függ, amely diszkrecionális jellegü, amennyiben a meghozatalára nem vonatkozik objektív és ellenőrizhető kritérium, és azt nem kell indokolni. Ezenkívül az ilyen döntéssel szemben nincs helye bírósági jogorvoslatnak. Egyébiránt a nemzeti igazságszolgáltatási tanács, amikor ilyen állásfoglalást kellett kiadnia a köztársasági elnöknek mielőtt ez utóbbi meghozta volna döntését, általában és indokolási kötelezettségét előíró szabály hiányában olykor bármiféle indokolás nélküli, olykor pusztán formális indokolást tartalmazó - akár kedvező, akár kedvezőtlen - állásfoglalásokat adott ki. Következésképpen az ilyen állásfoglalások nem járulhatnak hozzá ahhoz, hogy a köztársasági elnök objektív tájékoztatást kapjon az annak érdekében ráruházott 
diszkrecionális hatáskör gyakorlása keretében, hogy a 65. és 71. életév között kétszer hároméves időtartamra engedélyezze a legfelsőbb bíróság bírája feladatai ellátásának folytatását. A Bíróság megállapította, hogy e jogkör észszerű kétségeket ébreszt nevezetesen a jogalanyokban az érintett bírák külső tényezők általi befolyásolhatatlanságát, valamint az előtte ütköző érdekek vonatkozásában való semlegességét illetően.

\section{A C-64/16. sz. Associação Sindical dos Juízes Portugueses-ügy előzményei}

A portugál törvényhozó 2014 októberével kezdődő hatállyal és ideiglenes jelleggel csökkentette számos, közhivatalt ellátó vagy a közszolgálatban dolgozó személy, köztük a számvevőszék bíráinak az illetményét. E megszorító intézkedések alkalmazásának fokozatos megszüntetéséről egy 2015-ben elfogadott törvény rendelkezett, amely a szóban forgó intézkedések 2016. január 1-jével történő hatályon kívül helyezését írta elő.

Az Associação Sindical dos Juízes Portugueses (a portugál bírók érdekvédelmi szervezete) a számvevőszék bíráinak a nevében fellépve eljárást indított a portugál legfelsőbb közigazgatási bíróság előtt az említett költségvetési intézkedésekkel szemben. A szervezet szerint a bírák illetményének csökkentését elrendelő kérdéses intézkedések sértik a bírák függetlenségének az elvét, amelyet nemcsak a portugál alkotmány, de az uniós jog is elismer.

A portugál legfelsőbb közigazgatási bíróság előadása szerint a közszolgálatban dolgozók illetményének ideiglenes csökkentéséről szóló intézkedések az Európai Unió által Portugália számára elöírt azon kötelezettség teljesítésére vezethetők vissza, amely szerint a portugál államnak csökkentenie kell a költségvetésében keletkezett túlzott hiányt, amiért cserébe Portugália pénzügyi támogatásban részesül. A legfelsőbb közigazgatási bíróság ugyanakkor azt is hangsúlyozta, hogy a portugál állam is köteles tiszteletben tartani az uniós jog általános elveit, köztük a bírák függetlenségének az elvét, amely mind az uniós, mind pedig a nemzeti bíróságokra alkalmazandó. A legfelsőbb közigazgatási bíróság szerint ugyanis az uniós jogrendből származó jogok hatékony bírói védelmét elsősorban a nemzeti bíróságoknak kell biztosítaniuk, mégpedig a függetlenség és a pártatlanság elveinek a tiszteletben tartásával. A legfelsőbb közigazgatási bíróság kiemelte, hogy a bíróságok függetlensége függ az ott szolgálatot teljesítő bírák státuszához füződő garanciák tiszteletben tartásától, ideértve a bírák javadalmazását is.

Ilyen körülmények között a legfelsőbb közigazgatási bíróság azt kérdezte a Bíróságtól, hogy a bírák függetlenségének elvével összhangban van-e az a gyakorlat, hogy egy tagállam a közszolgálatban alkalmazandó illetmények általános hatályú csökkentésére irányuló intézkedéseket a bírói hatalom tagjaival szemben is alkalmazza, amennyiben ezen intézkedések a túlzott költségvetési hiány csökkentésére irányuló kötelezettségekhez, valamint az Unió egy pénzügyi támogatási programjához kapcsolódnak. 


\section{A Bíróság C-64/16. sz. Associação Sindical dos Juízes Portugueses-ügyben hozott ítélete}

2018. február 27-én meghozott ítéletében a Bíróság mindenekelőtt hangsúlyozta a hatékony bírói jogvédelem elvének a jelentőségét, amely elv az uniós jog a tagállamok közös alkotmányos hagyományaiból származó olyan általános elvének minősül, amelyet a Charta is elismer. Így a tagállamok feladata annak biztosítása, hogy a jogrendszerük az uniós jog által szabályozott területeken egy hatékony bírói ellenőrzési mechanizmust tegyen elérhetővé. A Bíróság szerint az uniós jog tiszteletben tartásának ellenőrzésére irányuló e mechanizmus megléte magának a jogállamiságnak a részét képezi.

Ebből következően valamennyi tagállamnak gondoskodnia kell arról, hogy jogorvoslati rendszerében az uniós jog által szabályozott területeken az uniós jog értelmében vett „bíróságnak” minősülő fórumok teljesítsék a hatékony bírói jogvédelem nyújtásához kapcsolódó követelményeket.

Amennyiben tehát a számvevőszéknek mint „bíróságnak” olyan kérdésekről kell döntenie, amelyek az uniós jog alkalmazását és értelmezését érintik - aminek az ellenőrzése a legfelsőbb közigazgatási bíróság feladata -, úgy Portugáliának biztosítania kell, hogy e fórum teljesítse a hatékony bírói jogvédelemhez kapcsolódó követelményeket.

A Bíróság hangsúlyozta, hogy egy ilyen fórum függetlenségének megőrzése alapvető fontosságú és szerves alkotórészét képezi az e fórum igazságszolgáltatási tevékenység ellátására irányuló megbízatásának. E követelmény tiszteletben tartását nemcsak az Unió, hanem a tagállamok szintjén, és így a nemzeti bíróságok tekintetében is biztosítani kell. A Bíróság emellett rámutatott arra is, hogy e követelmény alapvető jelentőséggel bír a nemzeti bíróságok és a Bíróság közötti igazságügyi együttműködés rendszerének megfelelő működése szempontjából is.

Ezzel összefüggésben a Bíróság pontosította, hogy a „függetlenség” fogalma előfeltételezi különösen azt, hogy az érintett fórum a bírósági funkcióit teljes körü autonómia keretében látja el anélkül, hogy bárkivel szemben bármiféle hierarchikus vagy alárendeltségi viszonyban állna, és anélkül, hogy bárhonnan utasításokat vagy iránymutatásokat kapna, továbbá azt, hogy védelmet élvezzen az olyan külső beavatkozással vagy nyomással szemben, amely veszélyeztetheti tagjai határozathozatalának függetlenségét, és határozataikat befolyásolhatja. A Bíróság mindehhez azt is hozzátette, hogy az érintett fórum tagjainak azon meggyőződése, hogy a javadalmazásuk szintje összhangban áll az általuk ellátott feladatok fontosságával szerves alkotórészét képezi a bírák függetlenségének.

Az elmondottakat szem előtt tartva ugyanakkor a Bíróság megállapította, hogy a közszolgálatban alkalmazott illetmények csökkentésére irányuló szóban forgó intézkedések nem sértik a számvevőszék bíráinak a függetlenségét. Ezen intézkedések ugyanis nemcsak a számvevőszék bíráira alkalmazandóak, hanem sokkal szélesebb körben, mégpedig különféle közhivatali funkciókat ellátó vagy a közszolgálatban dolgozó személyekre, köztük a törvényhozó, a végrehajtó és a bírói hatalom képviselőire. Olyan általános hatályú intézkedésekről van tehát szó, amelyek célja az, hogy 
a nemzeti közszolgálat valamennyi tagja járuljon hozzá a portugál állam költségvetésében keletkezett túlzott hiány csökkentésére irányuló takarékossági erőfeszítésekhez. Ezenkívül a kérdéses intézkedések időben korlátozottak voltak, mivel azok 2014. október 1-jén léptek hatályba, és 2016. október 1-jével véglegesen hatályukat veszítették.

\section{Zárszó}

A lengyel legfelsőbb bíróság bíráinak nyugdíjazását érintő üggyel kapcsolatban érdemes felidézni, hogy 2012 novemberében a bírákra vonatkozó nyugdíjkorhatár leszállítása miatt Magyarországot is elmarasztalta a Bíróság, ${ }^{2}$ ugyanakkor nem az EUSZ vagy a Charta szabályaiba beépített jogállamisági kritériumok, hanem a munka világában a hátrányos megkülönböztetés különféle formáit tiltó irányelv ${ }^{3}$ rendelkezéseinek megsértése miatt. A bírói kar egészének és az ügyészeknek a nyugdíjkorhatárát lecsökkentő lengyel törvény miatt indított, és jelenleg is folyamatban lévő kötelezettségszegési eljárásban ${ }^{4}$ a Bizottság egyszerre hívta fel az EUSZ, a Charta és az említett irányelv megsértését, ez utóbbit azért, mert a lengyel jogalkotó eltérő csökkentett nyugdíjkorhatárt állapított meg a női és a férfi bírák számára. A korábbi magyar ügyben a hátrányos megkülönböztetés az életkoron alapult, és a nyugdíjba küldött, valamint a szolgálatban maradt bírák között állt fenn.

Lengyelországból egyébként számos előzetes döntéshozatali ügy is érkezett a Bíróságra a bírák függetlenségével kapcsolatosan, különösen azt kifogásolva, hogy a végrehajtó és a törvényhozó hatalomnak túlzott ráhatása van a bíróságok működésére. ${ }^{5}$

A bírák javadalmazásával kapcsolatos portugál ügy apropóján emlékeztetni kell arra is, hogy a közelmúltban Magyarországról is érkezett egy előzetes döntéshozatal iránti kérelem ${ }^{6}$ a Bíróságra, amelyben egyebek mellett annak eldöntésére kérték fel az uniós bírákat, hogy az a körülmény, hogy a magyar bírák javadalmazása állítólagosan nem áll összhangban az általuk ellátott feladatok jelentőségével, azt eredményezi-e, hogy ez utóbbi bírák tekintetében sérül a bírói függetlenség elve. A szóban forgó magyar ügyben felmerült másik fontos kérdés az, hogy az Országos Bírósági Hivatal elnöke által a magyarországi bíróságok elnökeinek kinevezése tekintetében követtett gyakorlat sérti-e a bírák függetlenségének az elvét.

Végezetül fontos megemlíteni, hogy a bírák függetlenségével kapcsolatban az utóbbi hónapokban Romániából is számos ügy ${ }^{7}$ érkezett a Bíróságra, amelyek különösen a bírák által elkövetett jogsértések kivizsgálására felállított eljárási mechanizmusnak, valamint a bírák az igazságszolgáltatási tevékenységük során elkövetett hibákért való pénzügyi felelőssége megállapíthatóságának az uniós joggal való összhangjára vonatkoznak.

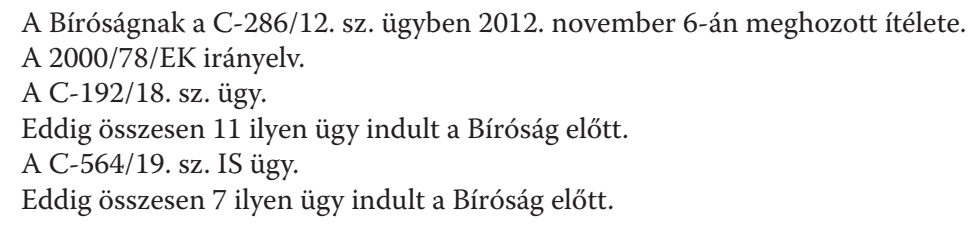

